\title{
Analisis Muatan Nilai-Nilai Karakter Pada Buku Siswa Kelas IV Sekolah Dasar Tema Indahnya Kebersamaan
}

\author{
Efan khairul ammar \\ SD Negeri 3 Bangkleyan, Kabupaten Blora \\ efan.khairulammar@gmail.com
}

\begin{abstract}
Abstrak
Penelitian ini bertujuan untuk mendeskripsikan muatan nilai-nilai karakter yang terdapat dalam buku siswa kelas IV Tema 1 Indahnya Kebersamaan. Penelitian ini termasuk penelitian deskripstif kualitatif dan merupakan jenis penelitian studi pustaka. Data dalam penelitian ini merupakan pernyataan-pernyataan yang mengandung nilai-nilai karakter. Teknik pengumpulan data dengan menggunakan teknik baca, teknik simak dan teknik catat. Metode analisis data yang digunakan adalah analisis teks dan bahasa dengan menggunakan teknik analisis isi (content analysis). Berdasarkan hasil analisis, dari 18 nilai-nilai karakter yang dicanangkan oleh Kemendiknas, ditemukan 17 nilai karakter dalam buku tematik kelas IV Tema 1 Indahnya Kebersamaan yaitu: (1) religius, (2) jujur, (3) toleransi, (4) kerja keras, (5) kreatif, (6) mandiri (7) demokratis, (8) semangat kebangsaan, (9) rasa ingin tahu, (10) cinta tanah air, (11) menghargai prestasi, (12) komunikatif, (13) cinta damai,(14) Gemar Membaca, (15) peduli lingkungan, (16) peduli sosial, dan (17) tanggung jawab. Hal ini berarti terdapat satu nilai karakter yang belum ditemukan yaitu nilai karakter disiplin.
\end{abstract}

Kata Kunci: Nilai-Nilai Karakter, buku siswa, Indahna Kebersamaan

\begin{abstract}
This study aims to describe the content of character values contained in the fourth grade students' themes 1 Theme of Beautiful Togetherness. This research is a qualitative descriptive research and is a type of library research. The data in this study are statements that contain character values. Data collection techniques using reading techniques, listening techniques and note taking techniques. Data analysis method used is text and language analysis using content analysis techniques. Based on the results of the analysis, of the 18 character values proclaimed by the Ministry of National Education, 17character values were found in Thematic book class IV Theme 1 The Beauty of Togetherness, namely: (1) religious, (2) honest, (3) tolerance, (4) hard work , (5) creative, (6) independent (7) democratic, (8) nationalism, (9) sense wanting to know, (10) love the motherland, (11) appreciating achievement, (12) communicative, (13) peaceful love, (14) ) loving reading, (15) environmental care, (16) social care, and (17) responsibilities. This means that there are one character values that have not been found, namely the discipline character value.
\end{abstract}

Keywords: Character Values, Student Book, The Beauty of Togetherness.

\section{PENDAHULUAN}


Arus modernsasi merupakan dampak yang terjadi pada saat ini yang mengakibatkan banyak orang berperilaku tidak baik. Berbagai perilaku kurang baik seperti remaja memakai obat-obatan terlarang, tawuran antar pelajar, mencontek, bulliying, berbagai tindakan asusila, dan lain sebagainya. Maka dari itu pendidikan karakter harus ditanamkan sedini mungkin. Pendidikan karakter harus dilakukan dalam dunia pendidikan maupun lingkungan sekitar. Pelaksanaan aktivitas kegiatan ekstrakurikuler, kegiatan kokurikuler pemberdayaan sarana prasarana, pembiayaan dan etos kerja seluruh warga sekolah dan lingkungan disekitarnya baik lingkungan sekolah maupun lingkungan rumah. Seperti yang diungkapkan oleh Utami (2015) Sehingga remaja dan anak-anak dapat memiliki karakter yang diinginkan oleh bangsa ini ketika mereka dewasa.

Tanpa karakter seseorang dengan mudah melakukan sesuatu tindakan yang menyinggung atau menyusahkan orang lain. Karena itu, kita harus membentuk karakter untuk mengolah diri dari hal-hal negatif, karakter yang terbangun diharapkan akan memotivasi setiap manusia untuk menjalankan sesuatu sesuai dengan suara hatinya.

Tumbuh dan berkembangnya karakter yang baik, dapat mendorong manusia untuk tumbuh sesuai dengan kemampuannya, untuk melakukan segalanya dengan benar. Oleh karena itu kita dapat membatasi kenakalan remaja dengan cara menanamkan pendidikan karakter sejak dini, supaya kenakalan remaja dapat diminimalisir.

Dalam membangun karakter yang baik menurut Zubaedi (2011) ada tiga hal yang saling berhubungan yaitu sebagai berikut karakter tersususn dari 3 bagian yang sama-sama berkaitan yakni: pengetahuan moral (moral knowing), perasaan moral (moral feeling), dan perilaku moral (moral behavior). Knowing the good (Karakter yang baik terdiri ilmu mengenai kebaikan), desiring the good (keinginan terhadap kebaikan), dan doing the good (berbuat kebaikan). Menurut Kemendiknas dalam (Rachmah, 2013) Dalam rangka lebih memperkuat pelaksanan pendidikan karakter pada satuan pendidikan telah terintegrasi 18 nilai yang bersumber dari agama, pancasila, budaya dan Tujuan Pendidikan Nasional yaitu: Religius, Jujur, toleransi, disiplin, kerja keras, kreatif, mandiri, demokratis, 
rasa ingin tahu, semangat kebangsaan, cinta tanah air, menghargai prestasi, bersahabat, komunikatif, cinta dami, gemar membaca, peduli lingkungan, peduli sosial, tanggung jawab.

Pemerintah menyadari betul kenakalan remaja dapat dicegah, upaya pencegahan dari pemerintah yaitu dengan cara menambahkan pendidikan karakter pada kurikulum 2013. Kurikulum 2013 menekankan pada pendidikan karakter yang di dapatkan sejak dini hal itu sesuai dengan landasan filosofis kurikulum 2013 yang terdapat pada Permendikbud Nomor 67 Tahun 2013 tentang kerangka Dasar dan Struktur Kurikulum SD/MI yaitu "proses pendidikan adalah suatu proses yang memberi kesempatan kepada peserta didik untuk mengembangkan potensi dirinya menjadi kemampuan berpikir rasional dan kecemerlangan akademik dengan memberikan makna terhadap apa yang dilihat, didengar, dibaca, dipelajari dari warisan budaya berdasarkan makna yang ditentukan olehlensa budayanya dan sesuai dengan tingkat kematangan psikologis serta kematangan fisik peserta didik".

Melalui pidato Presiden Susilo Bambang Yudhoyono pada tanggal 11 Mei 2010 dalam Daryanto (2013) yang menyatakan "Telah mencanangkan gerakan nasional pendidikan karakter. Melalui gerakan tersebut pemerintah berusaha mengembalikan pendidikan pada tujuan dasarnya, yang meliputi ketiga aspek yaitu, aspek kognitif, aspek afektif, dan aspek psikomotorik secara konsisten dan seimbang”. Dalam rangka mempersiapkan lulusan pendidikan memasuki era globalisasi yang penuh tantangan dan ketidakpastian, diperlukan pendidikan yang dirancang berdasarkan kebutuhan nyata di lapangan. Kurikulum 2013 ini merupakan kurikulum yang mengintegrasikan nilai-nilai karakter pada setiap pembelajarannya. Menurut Mulyasa (2014) "Kurikulum ini diarahkan untuk mengembangkan pengetahuan, pemahaman, kemampuan, nilai, sikap, dan minat peserta didik agar dapat melakukan sesuatu dalam bentuk kemahiran, ketepatan, dan keberhasilan dengan penuh tanggungjawab".

Pengimplementasian pendidikan karakter pada kurikulum 2013 yaitu dengan cara menambahkan nilai-nilai pendidikan karakter pada bahan pembelajaran. Bahan pembelajaran merupakan suatu sumber belajar yang disusun 
dengan baik, teratur, dan digunakan untuk membantu proses pembelajaran. Pada Kurikulum 2013 bahan pembelajaran yang mengintegrasikan pendidikan karakter terdapat dalam buku siswa. Buku siswa merupakan buku teks yang dipakai untuk mempermudah siswa mempelajari kompetensi tertentu. Maka dari itulah pada buku siswa kurikulum 2013 bukan hanya menekankan aspek pengetahuan (kognitif) tetapi juga harus ada aspek sikap (afektif) dan juga aspek keterampilan (psikomotorik).

Buku siswa merupakan buku yang diperuntukan kepada siswa yang difungsikan menjadi panduan aktivitas pembelajaran demi meringankan siswa dalam menguasai kompetensi tertentu. Buku siswa tidak sekedar menjadi bahan bacaan, namun juga dimanfaatkan sebagai pelaksanaan kegiatan-kegiatan dalam proses pembelajaran. Buku siswa disusun untuk memfasilitasi siswa agar mendapat pengalaman belajar yang bermakna. Siswa akan sering membaca dan mengerjakan tugas dari buku siswa terutama saat pembelajaran berlangsung, sehingga buku siswa dapat mempengaruhi perkembangan karakter siswa. Oleh sebab itu, buku siswa dapat dikatakan sebagai media yang strategis untuk mengembangkan karakter siswa. Buku siswa yang memuat hal-hal positif, termasuk karakter yang baik akan turut serta mengakibatkan perkembangan ke arah yang positif dalam diri siswa (Muslich, 2010:20). Isi sajian buku dimaksudkan agar siswa makin aktif saat mengikuti proses pembelajaran dengan kegiatan mengamati, menanya, menalar, mencoba, berdiskusi dengan meningkatkan kemampuan berkomunikasi baik antar teman maupun bersama guru.

Berdasarkan uraian latar belakang di atas peneliti ingin menunjukkan macam-macam nilai karakter yang terkandung dalam Buku Tematik Kelas IV Tema 1 Indahnya Kebersamaan. Tujuan penelitian ini yaitu mendeskripsikan muatan nilai-nilai karakter yang terkandung dalam buku siswa kelas IV Sekolah Dasar tema indahnya kebersamaan. Penelitian ini diharapkan dapat menjadi pedoman untuk menanamkan nilai karakter pada anak sejak usia dini.

\section{METODE PENELITIAN}


Penelitian ini menggunakan pendekatan kualitatif dengan jenis penelitian deskriptif. Menurut Sugiyono (2017: 9), penelitian kualitatif merupakan penelitian yang digunakan untuk meneliti objek yang alamiah, peneliti sebagai instrumen kunci, teknik pengumpulan data dilakukan secara triangulasi (gabungan), analisis data bersifat induktif/kualitatif, dan hasil penelitiannya lebih menekankan makna daripada generalisasi. Penelitian ini memiliki tujuan yaitu menemukan makna di balik suatu fenomena berdasarkan data yang sudah diperoleh kemudian dianalisis dengan cara yang mendalam. Jenis penelitian yang digunakan adalah studi pustaka atau penelitian pustaka. Jenis penelitian studi pustaka ini digunakan untuk meneliti informasi tertulis yaitu nilai-nilai karakter yang terdapat pada buku siswa tema Indahnya Kebersamaan kelas IV Sekolah Dasar yang diterbitkan oleh Kemdikbud.

Pengumpulan data dalam penelitian ini dengan membaca, menyimak dan mencatat. Teknik baca digunakan karena dalam memperoleh data digunakan tahap membaca yaitu buku tematik kelas IV tema 1 Indahnya Kebersamaan. Teknik simak yaitu melakukan penyimakan terhadap data secara cermat. Berdasarkan penyimakan secara cermat dan teliti itu kemudian dilakukan teknik selanjutnya yaitu teknik catat dengan mencatat hasil penyimakan pada buku tersebut.

Keabsahan data dalam penelitian ini menggunakan validitas dan reliabilitas. Validitas yang digunakan dalam penelitian ini adalah "validitas semantik". Validitas dilakukan untuk mengetahui kesesuaian makna teks dengan konteks yang dipilih. Reliabilitas yang digunakan dalam penelitian ini adalah reliabilitas stabilitas dan reliabilitas replikabilitas. Reliabilitas stabilitas dilakukan dengan pembacaan berulang untuk mendapatkan pemahaman, sedangkan reliabilitas replikabilitas dilakukan dengan cara diskusi dan konfirmasi dengan teman sejawat, untuk dapat memberi masukan terkait hasil analisis.

Metode analisis data penelitian ini menggunakan analisis isi (Content Analysis) yaitu teknik penelitian untuk membuat inferensi- inferensi yang dapat ditiru (replicabel), dan sahih data dengan memperhatikan konteksnya (Burhan 2011: 231). Dalam hal ini digunakan untuk menganalisis nilai-nilai karakter dalam buku tematik kelas IV tema 1 Indahnya Kebersamaan. 


\section{HASIL PENELITIAN DAN PEMBAHASAN}

\section{a. Hasil Penelitian}

Susunan buku meliputi halaman sampul yang memuat judul buku, yaitu: Indahnya Kebersamaan (Buku Tematik Terpadu Kurikulum 2013) Tema 1. Buku ini diperuntukkan bagi siswa SD/MI kelas IV, artinya buku ini diterapkan untuk SD umum dan MI, yaitu sekolah yang dikelola oleh lembaga keagamaan. Sistematika isi buku, mencakup: penulis buku, kata pengantar, tentang buku siswa, kata pengantar, tentang buku siswa, daftar isi, subtema, pembelajaran, daftar pustaka, profil penulis, profil penelaah, profil editor, profil illustrator.

Pola penulisan buku ini disajikan dalam bentuk subtema dengan sajian sebagai berikut a) Subtema 1 Indahnya Kebersamaan (Halaman 174) b) Subtema 2 Kebersamaan dalam Keberagaman (Halaman 75-128) c) Subtema 3 Bersyukur atas Keberagaman (Halaman 129-179)

Kesesuaian komponen buku dan pedoman penyusunan buku tematik kelas IV tema 1 Indahnya Kebersamaan mempunyai komponen meliputi judul buku, halaman penerbit, hlaman kata pengantar, halaman daftar isi, penomoran halaman, bab, judul bab, penanda bagian bab, informasi pelaku penulis, ilustrasi biodata penulis, ilustrasi biodata ilustator dan daftar pustaka. Komponen buku teks belum sesuai dengan pedoman penysunan buku teks karena dalam buku tersebut belum terdapat indeks dan lampiran.

Berdasarkan hasil penelitian yang telah dilakukan, ditemukan banyak nilai karakter pada Buku Siswa Tematik Integratif kurikulum 2013 Kelas IV Sekolah Dasar tema Indahnya Kebersamaan. Nilai adalah kualitas suatu hal yang menjadikan suatu hal itu disukai, diinginkan, dikejar, dihargai, berguna dan dapat membuat orang yang menghayatinya menjadi bermartabat.

Hasil penelitian tentang muatan nilai karakter pada buku siswa kelas IV Sekolah Dasar semester 1 Kurikulum 2013 didasarkan pada muatan nilai-nilai karakter yang sesuai dengan UU sisdiknas no 20 tahun 2003 dan dijelaskan dalam buku Salahudin (2013: 111), tentang nilai karakter yang perlu ditanamkan dalam pembelajaran. Nilai karakter yang dimaksud adalah (1) religius (2) jujur (3) 
toleransi (4) disiplin (5) kerja keras (6) kreatif (7) mandiri (8) demokratis (9) rasa ingin tahu (10) semangat kebangsaan atau nasionalisme (11) cinta tanah air (12)menghargai prestasi (13) bersahabat/komunikatif (14) cinta damai (15)gemar membaca (16) peduli lingkungan (17) peduli sosial (18) tanggung jawab.

Nilai karakter yang disajikan, tidak berdiri sendiri sebagai suatu materi pelajaran. Nilai karakter yang hendak disampaikan diintegrasikan dalam materi pelajaran. Nilai karakter yang disajikan terintegrasi ditemukan cukup banyak dalam buku siswa. Penyampaian nilai karakter pada hakikatnya tidak dapat dipisahkan dengan materi pelajaran. Hal ini sejalan dengan yang ditegaskan Hidayatulloh (2010: 55) bahwa nilai karakter disajikan secara terintegrasi karena memang tidak dapat dipisahkan dengan aspek lain dan merupakan landasan seluruh mata pelajaran. Hal ini dimaksudkan agar pendidikan tidak hanya membuat seorang siswa pintar, tetapi juga berkarakter. Dengan demikian, siswa dapat menggunakan ilmu yang dimilikinya untuk kebaikan.

Pada proses analisis nilai karakter pada buku siswa ditemukan pembelajaran yang melibatkan peserta didik untuk melakukan kegiatan yang berkaitan dengan diri sendiri, teman sebaya, orang lain, dan masyarakat. Kegiatan tersebut ditemukan pada beberapa pembelajaran yang mengandung nilai karakter tertentu dan sifatnya berulang-ulang dalam setiap pembelajaran. Pengulangan tersebut dilakukan sebagai suatu pembiasaan bagi peserta didik terhadap nilainilai karakter. Dibutuhkan proses panjang dan berkelanjutan agar karakter dapat menjadi bagian integral dalam diri (Naim, 2012: 18). Proses panjang dan berkelanjutan tersebut terlihat dari beberapa kegiatan pembelajaran pada buku siswa, yaitu berupa pembiasaan baik yang melatih peserta didik untuk berpikir, berucap, dan bertindak dengan baik. Nilai-Nilai Karakter yang terdapat dalam Buku Tematik Kelas IV Tema 1 Indahnya Kebersamaan Berdasarkan hasil baca, simak, dan catat yang telah dilakukan, nilai-nilai karakter yang telah ditemukan dapat diuraikan sebagai berikut:

Tabel 1. Pemetaan nilai-nilai karakter

\begin{tabular}{lll}
\hline No & Nilai Karakter & Jumlah \\
\hline 1 & Religius & 16 \\
\hline
\end{tabular}




\begin{tabular}{lll}
\hline 2 & Jujur & 1 \\
3 & Toleransi & 15 \\
4 & Disiplin & 0 \\
5 & Kerja Keras & 33 \\
6 & Kreatif & 10 \\
7 & Mandiri & 1 \\
8 & Demokratis & 2 \\
9 & Rasa Ingin Tahu & 15 \\
10 & Semangat Kebangsaan & 3 \\
11 & Cinta Tanah Air & 25 \\
12 & Menghargai Prestasi & 2 \\
13 & Komunikatif & 24 \\
14 & Cinta Damai & 2 \\
15 & Gemar Membaca & 18 \\
16 & Peduli Lingkungan & 2 \\
17 & Peduli Sosial & 4 \\
18 & Tanggung Jawab & 2 \\
\hline
\end{tabular}

\section{Pembahasan}

Berdasarkan tabel data dan klasifikasi nilai karakter di atas dapat diketahui bahwa banyak nilai karakter yang ditemukan dalam buku siswa indahnya kebersamaan. Nilai karakter yang ditemukan memiliki frekuensi kemunculan yang berbeda-beda pada setiap pembelajaran. Nilai karakter yang banyak ditemukan adalah nilai-nilai kerja keras (33), cinta tanah air (25), dan komunikatif (24). Sementara itu, untuk nilai-nilai karakter yang lain juga ditemukan tetapi tidak sebanyak ketiga nilai tersebut.

Nilai karakter yang beragam pada dasarnya menjadikan banyak hal yang dapat digunakan sebagai acuan. Artinya, dalam buku siswa kelas IV indahnya kebersamaan tersebut siswa dan guru tidak hanya mendapati satu atau dua nilai karakter yang dapat digunakan sebagai contoh. Dengan begitu, akan banyak nilai yang mampu membuat siswa dan guru lebih berkarakter. Karakter kerja keras 
menjadi nilai yang sering muncul dalam buku siswa kelas IV indahnya kebersamaan. Siswa diharapkan memiliki perilaku yang menunjukkan upaya sungguh-sungguh dalam mengatasi berbagai hambatan guna menyelesaikan tugas (belajar/pekerjaan) dengan sebaik-baiknya.

Karakter cinta tanah air sangat perlu diberikan atau dimasukan dalam buku siswa. Siswa diharapkan memiliki sikap yang dilandasi ketulusan dan keikhlasan yang diwujudkan dalam perbuatan untuk kejayaan tanah air dan kebahagiaan bangsanya. Karakter lain yang penting dimiliki oleh siswa dan sudah ditemukan dalam buku siswa kelas IV indahnya kebersamaan adalah nilai karakter komunikatif. Siswa diharapkan memiliki sikap dan tindakan yang mendorong dirinya untuk menghasilkan sesuatu yang berguna bagi masyarakat, dan mengakui, serta menghormati keberhasilan orang lain. Dengan adanya nilai karakter tersebut didalam buku siswa kelas IV indahnya kebersamaan diharapkan siswa akan mampu mencontoh dan nilai karakter tersebut dapat tertanam dengan kuat.

Nilai yang belum banyak ditemukan didalam buku siswa tersebut adalah nilai jujur (1), mandiri (1), demokratis (2), menghargai prestasi (2), cinta damai (2), peduli lingkungan (2), dan tanggung jawab (2). Sedangkan nilai karakter yang belum ditemukan didalam buku siswa tersebut adalah nilai disiplin (0). Nilai-nilai tersebut secara tersirat maupun tersurat belum banyak ditemukan. Tidak dapat dipungkiri bahwa nilai-nilai karakter tersebut sangat penting untuk dimiliki, baik siswa maupun guru.

Hal ini didukung dengan hasil penelitian yang dilakukan Ridwan dan Mudiono (2017) yang berjudul, “Analisis Muatan Nilai-Nilai Karakter Pada Buku Siswa Kelas IV Sekolah Dasar Tema Indahnya Kebersamaan”. Kesimpulan penilitian ini adalah pengembangan nilai karakter religius, percaya diri dan peduli sudah dilakukan dengan cukup baik. Sementara itu, nilai karakter jujur, disiplin, santun, dan tanggung jawab masih perlu dikembangkan.

Kurikulum 2013 menggunakan pendekatan saintifik dalam proses pembelajarannya. Berdasarkan hasil analisa, buku siswa kelas IV indahnya kebersamaan sudah sesuai dengan kurikulum yang ada. Setiap subtema pada buku 
teks terdiri dari kegiatan belajar yang bersifat mengajak dan aktifitas belajarnya berdasarkan pendekatan saintifik, yaitu mengamati ("Ayo Membaca” dan "Ayo Mengamati”), mencoba (“Ayo Mencoba”, “Ayo Berlatih”, “Ayo Berkreasi”), menalar ("Ayo Berdiskusi"), dan mengkomunikasikan ("Ayo Bercerita" dan "Ayo Menulis"). Ada pula "Kegiatan Bersama Orang Tua" yang secara implisit mengajarkan agar siswa belajar di sekolah maupun di rumah, sehingga menunjang pencapaian standar lulusan 3 yaitu, mencerminkan sikap pembelajar sejati sepanjang hayat. Secara umum, upaya pengarang buku siswa untuk mencapai lima sikap pada standar lulusan dilakukan melalui teks bacaan maupun aktifitas belajar lainnya.

\section{SIMPULAN}

Berdasarkan hasil analisis Buku Tematik Kelas IV Tema Indahnya Kebersamaan terdapat komponen buku sebagai berikut: halaman sampul buku yang memuat judul buku, sistematika buku yang mencakup (Penulis Buku, kata pengantar, tentang buku siswa, daftar isi, subtema, pembelajaran, daftar pustaka, profil penulis, profil penelaah, profil editor, profil illustrator), dan terdapat 3 subtema yaitu a) Indahnya Kebersamaan b) Kebersamaan dalam Keberagaman c) Bersyukur atas Keberagaman.

Nilai-Nilai karakter yang ditemukan berdasarkan hasil analisis Buku Tematik Kelas IV Tema 1 Indahnya Kebersamaan, terdapat 16 nilai karakter sebagai berikut: (1) Religius, (2) Jujur, (3) Toleransi, (4) Kerja Keras, (5) Kreatif, (6) mandiri, (7) Demokratis, (8) Semangat Kebangsaan, (9) Rasa Ingin Tahu, (10) Cinta Tanah Air, (11) Menghargai Prestasi, (12) Komunikatif, (13) Cinta Damai, (14) Gemar Membaca, (15) Peduli Lingkungan, (16) Peduli Sosial, (17) Tanggung Jawab. Berdasarkan hasil analisis tersebut terdapat satu nilai karakter yang belum ditemukan yaitu nilai karakter disiplin.

Setelah melakukan analisis nilai karakter pada Buku Siswa Tematik Integratif Kurikulum 2013 Kelas IV SD/MI tema Indahnya Kebersamaan, peneliti menyarankan kepada guru-guru Sekolah Dasar untuk mengetahui kandungan nilai karakter yang terdapat pada buku teks pelajarannya, sehingga tidak hanya 
mengutamakan pengetahuannya saja melainkan juga menumbuhkan nilai-nilai karakter yang terdapat dalam buku tersebut pada proses pembelajarannya. Berhubung muatan nilai-nilai karakter dalam buku siswa kelas IV Tema Indahnya Kebersamaan belum semua nilai karakter termuat, maka dalam pembelajaran guru perlu memberi contoh dan langsung mempraktikkan agar dapat diterapkan dalam kehidupan sehari-hari.

Bagi pengembang buku ajar kelas IV Tema Indahnya Kebersamaan, perlu menambahkan teks-teks yang memuat nilai-nilai karakter yang belum ada, sehingga dapat meningkatkan kualitas buku yang telah dikembangkan terutama berkaitan dengan muatan nilai-nilai karakter yang ada di dalam buku siswa.

\section{DAFTAR PUSTAKA}

Akbar, Sa'dun. 2013. Instrumen Peningkatan Pembelajaran. Bandung. PT. Remaja Rosdakarya.

Bungin, Burhan. 2011. Penelitian Kualitatif. Jakarta: Kencana Predana Group.

Daryanto dan Darmiatun, Suryatri. 2013. Implementasi Pendidikan Karakter di Sekolah. Yogyakarta: Gava Media.

Hidayatulloh, F. 2010. Pendidikan Karater, Membangun Peradaban Bangsa. Surakarta:Yuma Pustaka.

Kemendikbud. 2013. Peraturan Menteri Pendidikan dan Kebudayaan Nomor 64 Tahun 2013, tentang Standar Isi Pendidikan Dasar dan Menengah. Peraturan Menteri Pendidikan dan Kebudayaan Nomor 67 Tahun 2013, tentang Kerangka Dasar dan Struktur Kurikulum SD/MI.

Mulyasa. 2012. Manajemen PAUD. Bandung: Remaja Rosdakarya. . 2014.Pengembangan dan Implementasi Kurikulum 2013. Bandung: PT Remaja Rosdakarya.

Muslich, M. 2010. Text Book Writing: Dasar-dasar Pemahaman, Penulisan, dan Pemakaian Buku Teks. Yogyakarta: Ar-Ruzz Media.

Naim, N. 2012. Character Building: Optimalisasi Peran Pendidikan dalam Pengembangan Ilmu dan Pembentukan Karakter Bangsa. Yogyakarta: ArRuzz Media. 
Rachmah, Huriah. 2013. Nilai-Nilai Dalam Pendidikan Karakter Bangsa Yang Berdasarkan Pancasila dan UUD 1945. Cimahi: Jurnal. Vol. 1, No. 1: 1113.

Ridwan, Mudiono. 2017. Analisis Muatan Nilai-Nilai Karakter Pada Buku Siswa Kelas IV Sekolah Dasar Tema Indahnya Kebersamaan. Jurnal Pendidikan $3(1), 1-7$.

Salahudin, Anas. 2013. Pendidikan Karakter. 076-366-1. Bandung : CV. Pustaka Setia.

Sugiyono. 2017. Metode Penelitian Kuantitaif, Kualitatif dan R\&D. Bandung: ALFABETA.

Utami, Ratnasari Diah. 2015. Membangun Karakter Siswa Pendidikan Dasar Muhammadiyah Melalui Identifikasi Implementasi Pendidikan Karakter Di Sekolah. Jurnal Profesi Pendidikan Dasar (JPPD). Vol.2, No. 1, Juli 2015.

Zubaedi.2011. Desain Pendidikan Karakter. Jakarta: Prenada Media Group. 